〔第45回総会シンポジウムーX線撮影技術の動问と将来展望〕

\title{
3. $\mathrm{X}$ 線撮影法の作成技術と今後の臨床技術
}

\author{
川村義 彦
}

日本医科大学付属病院放射線科

Key words: Positioning, plain radiographic technique, three-dimension, radiography of foramen opticum, image information for medical use

\section{TENDENCY OF RADIOGRAPHIC TECHNOLOGY AND PROSPECTS FOR THEM IN FUTURE \\ -Formation technique and future clinical technique of radiography-}

\author{
YOSHIHIKO KAWAMURA
}

Department of Radiology, Nippon Medical School Hospital

\section{Summary}

I made a report to this Symposium relating to positioning out of the radiographic techniques. It indicated present problems to be solved before discussing the prospects for the techniques in the future.

First, I pointed out the necessity of rearranging the present radiography so that it could stand up as technology more firmly. For this purpose, it is necessary to grasp the process of forming the radiography techniques systematically and newly put them in order.

Secondly, an analysis of the tendency of making use of radiography showed that it was advancing in the direction of metric diagnosis and that there were demands for highly precise and reproducible X-ray images. I remarked that it was a subject to be solved how technologists meet such demands. That is, we are now at a turning point in dealing with technical steps.

Thirdly, I stressed the importance of systematically constructing radiographic techniques on the basis of diagnosing physicians' demands for them. This can be said to be natural from the viewpoint of communicating $\mathrm{X}$-ray image information, too.

The report showed an outline of the flowchart of radiographic technique construction (a continuous flow from appearance of diagnosing physicians' demands to technical evaluation of radiography). To explain this outline, I gave the radiography of foramen opticum as an example.

As the fourth subject, the respective items of the flowchart need be put in order to establish the radiographic techniques for various sites. This requires accumulation of technical data. Promotion of full-scale use of databases is also believed to be needed.

Those subjects are thought to be the items first to be solved in considering the future of the radiographic technologies.

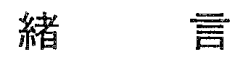

$\mathrm{X}$ 線単純撮影法は, X線発見以来の歴史があり, 伝統 のある技術として多くの部位の撮影に用いられている。 
現在，用いられている撮影法は，数多く作られたものの 中から，臨床に役立つもののみが残されてきたといえる.

一方, 現在の撮影技術は, 従来にも増して疾患・病態 に合わせた撮影技術に進むべきであるといわれ，第 9 回 の技術シンポジウムでも取り上げられ検討されている.

そこでは，従来，有用であるとされている撮影法でも， 最新の医療水準に見合ったX線像の要求から，もう一度 考えなおし整理をしてみることが必要であるとされだ。

X線単純撮影法に関しては，技術学会でとりあげられ 専門委員会における, 撮影法検討班の実態調查 ${ }^{2}$ や, 撮影 法標準化検討班の見直し作業 ${ }^{31}$ が進められているのが現 状である．撮影法を体系的に整理する方法についてはわ れわれも，そのまとめ方を検討し報告している 撮影法を考え直し整理するにあたっては，共通の認識の 上に立って，統一した方法で行う必要があり，まず，共 通の理解と認識の必要性がさけばれている.

このような実態をろまえて，本稿では，改めてX線写 真の利用動向を調べ撮影技術になにが要求されているの か, 撮影技術研究の現状はどのようになっているのか, 単純撮影法はどのようにまとめられてきたのか，その課 題は何かについて文献調查を行い, その結果から撮影法 を考えなおし検討する方法・枠組みの必要性を明らかに したい。そして，撮影法を考えなおし検討する方法には， どのような項目を起こし，どのような内容の整理をする べきなのか, どのようなまとめ方をするべきなのかにつ いて考え方をのべてみたい。

\section{1. 単純 $\mathbf{X}$ 線写真の利用動向調査からの 撮影技術の検討}

単純 $\mathrm{X}$ 線写真及び骨 $\mathrm{X}$ 線写真は, 疾患描出能の限界も 指摘されているが，それなりに有効であるという評価が 一般的となっており，骨X線写真の利用動向をみると， 要求が全体像把握のためのロードマップとしての概観像 と, 骨・関䬦などの計測のための精密画像という二つに 分類され, 明確にされている ${ }^{6,7,8)}$.

ここでは，その中の計量診断について，その動向を調 查し，その結果をもとに技術のあり方を考えてみたい。

単純 $\mathrm{X}$ 線写真の計量診断の利用動向を, 文献・書籍を 調査し, その結果と関連する撮影技術を対比させ, 今後 の撮影技術の対応を調べた。

Fig. 1 は，単純X線写真による計量診断法の発表の動 向を, 整形外科分野では，廣島ら ${ }^{9.10)}$ のデー夕を，臨床全 般では, Keats, Lustedら"リの゙ー一タ用いて得た結果 である，図は横軸に発表年をとり，縦軒を各年代の発年
PROGRESS OF PUBLICATIONS ON METRICAL DIAGNOSTICS CURRELTLY IN USE (only plain radiographs)

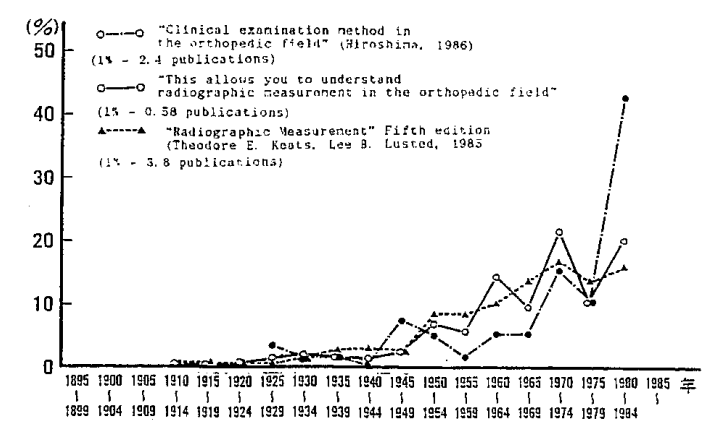

Fig. 1 Progress of publications on metric diagnosis currently in use. Two publications show data of the orthopedic field and the other one demonstrates data of the entire clinical field.

数の全計量診断法に対する百分率で表している。計量診 断法の発表の動向は，臨床全般ではなだらかに増加し， 整形外科分野では，ここ数年で急激な計量診断法の開発 へと進んでいる事を示した。

次に，増加傾向にある整形外科分野の計量診断の要求 内容を, 先の廣白らの文献9,10) を用いて調べた結果, その 利用動向の分類と利用比率は, 下のようになった。

不安定性・異常可動性計測 $\cdots 10 \%$

アライメント計測………....60\%

形態計測・ $30 \%$

ここでの不安定性・異常可動性計測の分類とは, 不安 定性・異常可動性の距離や角度デー夕にあたり，アライ メント計測は, 角度・距離の偏位・比指数などで, 形態 計測は，大きさ・形・幅・厚さ・深さ・高さ・長さ・径 などとその比指数を振り分けた。

整形外科分野では，ここ数年で急激な計量診断法の開 発へと進んでいる事が分かった．要求内容の傾向をみる と, 整形外科分野の計量診断は, アライメント計測が60 \%と大きな比率を占めている。このアライメント計測と 不安定性・異常可動性計測を合わせると70\%にも達する 計量診断となるが, 雨者に共通しているのは, 可動性の コントロールという機能解剖学的な要因となる.

使用比率からみて, 今後, この機能解剖という面から の技術の組み立てを，積極的に取り入れていく必要があ る. 特に，スポーツ整形外科分野 ${ }^{12,13)}$ 加らの要求が増大

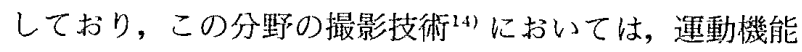
解剖の理解が必須なことから，一尿の技術研究が必要と 考えられる。

一方，これらの計量彰断は，X線写真に高い画像描出 
精度を要求しているが，大貫はこの点をとらえ，利用サ イドからの訴容できる誤差などの数量的な提示が明碓で ない場合もあるとし，また，技術茾イドからの正確な技 術データの提示がないなどの曖昧性の改善を提言してい $3^{15)}$ 。放射線医療技術灆書 (1) の放射線技術 QC プログ ラム ${ }^{16)}$ に㧈ける一般撮影分野の排除基準は，この函像精 度と関連しているが，数量的に明確に示されている部分 は少なく，計量診断に関わる数值は今のところ提示され ていない状態となっている。これはX線写真の利用評洒 がパタン認識という数量で割り切れない利用の仕方であ ることから，X線写真の品質に関して，数值で明確に提 示できなかったものと考えられる。しかし，計量䛦断分 野での数値表示による排除基準などは，今後まとめられ るべきもので，そのために一層の技術研究が必要となる。

\section{2. 単純 X 線撮影技術研究の変遷とその 課題}

\section{1 単純 X線撮影技術研究の変遷と今後の課題}

撮影技術の研究はどのように推移したかを検討し，今 後の課題を明らかにする。

技術史委員会のまとめた資料 ${ }^{17)}$ と，最近の10年間の学 会総会発表から単純撮影技術の研究発表 ${ }^{18)}$ を調查し，そ の結果から今後の技術研究のあり方を考察した。

Fig. 2 は技術史委員会のまとめた技術研究の動向を示 したもので，単純撮影技術は 6 期の昭和 $45 \sim 49$ 年がピー クを示しており，単純撮影技術の研究は，他の撮影技術 分野と比較して少なく，しかも減少傾向を示している。

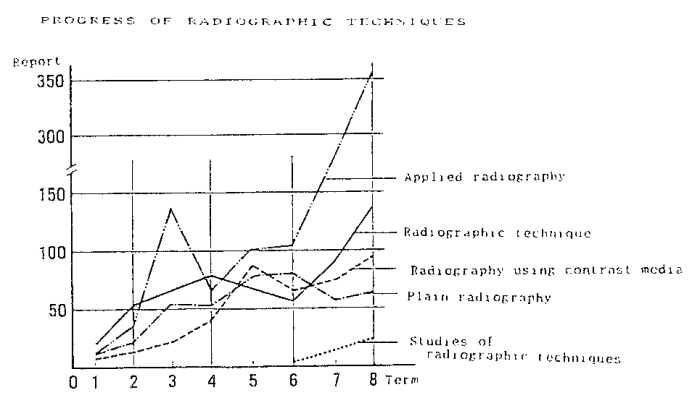

Fig. 2 Progress of publications of researches on radiographic techniques (Quotation from literature 17)

最近の10年間の学会総会発表から単純撮影技術の研究 発表の動向を調查した結果では，全演題数に対する単純 撮影演題数の比率は，全演題数がそれ程変動していない 状態での $3 \%$ 程度，平均で14演題であった。研究の内容 は，計量診断や，骨置換術などに関するもので，どちら かと言えば，より精密な撮影で，臨床要求に添った発表
の傾向にあった。

研究発表数の比較では，他の分野よりも少なく，しか も，減少傾向かもしくは，横ばい状態を示しており，先 の計量彭断の要求からしても, もつと活発な研究がなさ れるべきと考えら机る。また，研究の動向をみると，第 42回総会座長セッションでの大塚の集約 ${ }^{19)}$ と同じよう に，踟床の要求に即した技術開発がなされている結果と なり，計量邶断のための技術開発が行机れるなど，適切 な対応がなされていると考光られる。

しかし，この分野の研究は活発ではなく，今後は計量 診断分野の撮影技術の研究が促進されるように，何等か の組織だった形での研究体制がとられるべきではないか と思秃る。

\section{2 日本における X 線単純撮影法の研究はどのよう に進められてきたのか (視神経管撮影法を例にし て)}

日本に括けるX線単純撮影法は，どのようにまとめら れてきたのかを，視神経管撮影法を例にして検討する。

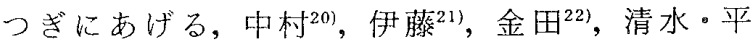

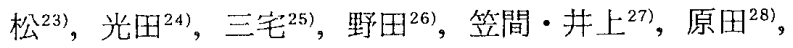

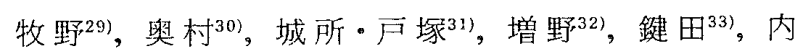
藤 $^{34)}$, 山岸 ${ }^{35)}$, 湯浅 ${ }^{36)}$, 森 [ ${ }^{37)}$ らの視神経管撮影法を対象 にして,

（1）つぎの3つの撮影法の組み立て方の利用頻度を調 ベた。「1）Hartman 法38) やGoalwin ${ }^{39)}$ 法に代表さ机 る，正中矢状面との角度抢よび，ドイツ水平面などの基 準線・面との角度の相関データを利用した撮影法，2） Brunetti 法 ${ }^{401}$ に代表される，X線の入射点と射出点を何 等かの相関データで求めてそれを利用した撮影法，3） Busi 別法 ${ }^{411}$ に代表さ杴る, 視神経管の走行と相関のある 他の部位のデー夕を利用した撮影法,」

(2) Pfeiffer 法 ${ }^{42)}$, Lysholm 法 ${ }^{43)}$, Camp \& Gianturco 法44) 撮影などのように特殊装置（撮影台および補助具な ど）を考えた撮影法の比率を調べた。

（3）研究が独自なものか追試なのかをつぎの分類でそ の頻度を調べた。「 a ) 欧米の研究の追試，b）欧米の撮 影法の日本人の体型への補正研究，c）既存の撮影法の 改良研究，d）独自な撮影法の研究」

（1）撮影法の組み立て方の利用頻度は，不明の一つを 除き，正中矢状面との角度招よび，ドイツ水平面などの 基準線・面との角度の相関デー夕を利用した方法が 61.1 $\% ， \mathrm{X}$ 線の入射点と射出点を何等かの相関データを求め てそ狄を利朋した方法が $27.8 \%$ ，視神経管の走行と相関 のある他の部位のデータを利用した方法が $11.1 \%$ となつ 
た.

（2）撮影台および補助具などを用いた撮影法は, 全体 の $66.7 \%$ になった。

（3）研究が独自なものか追試なのかの分類は，その違 いを明確に記述されているものもあるが，不明なものが 相当数にのほり, 正確な比率を求めることができなかっ た.

視神経管撮影の目的は, 視神経管の正しい解剖学的軸 方向像を得ることであり，しかも見えない部位の撮影で あることから，分類した三つの方法のどれを用いて撮影 法を作ってもよいことになるが，撮影法の組み立て方の 利用頻度をみると，人体の基準線・面を用いた技術の組 み立てが約 $60 \%$ しめていた．視神経管は入射点・射出 点を求めて行う対向点撮影法が比較的良好な結果を得る 部位にも関わらず，その研究開発は，約 $30 \%$ 程度に留ま っている.このことは，撮影法の作成には人類学的な基 準線・面を利用するという考元方が基本にあることを証 明しているものと考えられる。

さらに，撮影法の組み立て方が異なったとしても，撮 影台および補助具などを用いて実際の撮影法を組み立て ていこうとする考え方は, 全体の70\%近くにも達してい る.

これは体表から見えない部分の正しい設定のためには， 器具を用いて行うことを基本に考えていることを示すも のである。

研究が独自なものか追試なのかの正確なデー夕を求め ることができなかったが，研究はつぎのような傾向にあ つた。

a ) の欧米の研究の追試の例は, 撮影法の導入の最初 に行われる研究であるが，論文として揭載されているも のは少なかった。収集の論文中では, Camp \& Gianturco

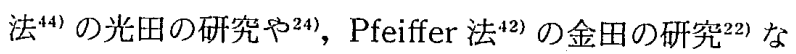
ど初期の研究にみられていた。

b）の欧米の撮影法の日本人の体型への補正研究は, Goalwin ${ }^{39}$ 法に基づく中村の統計的な研究20) が, その代 表的なものとなっている.

c）の既存の撮影法の改良研究は, 最も多くみら机る 研究となっている.

この既存の撮影法の改良研究は, 視神経管に限らず, その他の部位でも取り入れられ用いられており，撮影法 の研究開発の相当数を賄っている方法となっている.

d）の独自な撮影法の研究は少なく, 視神経管撮影で は戸塚の研究 ${ }^{31}$ が優れたものとして評価されている.

日本におけるX線撮影法の研究開発は, 欧米の撮影法
を日本人の体型に合わせた補正研究か，あるいは既存の 撮影法の改良研究が多かったことから，わずかの違いの 撮影法も数多く発表されるに至っている.

さらに，いくつかの撮影法の長所を取り入れた撮影法 も作られ，同一撮影法の名称でも僅かに異なる内容の撮 影法が数多く存在することにもつながったのではないか と考えられる。

2.3 日本における X線単純撮影法の研究はどのよう にまとめられてきたのか(視神経管撮影法を例に して)

日本におけるX線単純撮影法は，どのようにまとめら れてきたのかを，視神経管撮影法を例にして検討した。

欧米の撮影法も含めた視神経管撮影法の研究が, 日本 の書籍の上で，どのようにまとめられたか，どれ程内容 が異なるかを入手できた書籍45 51) から比較した。

入手できた書籍の記述内容をまとめると Table 1 の結 果となった。表は研究発表のオリジナルと同じ記述の場 合, 撮影法の名称のみを記入し，本の著者のオリジナル と推測されるものは，その角度数值を記載してまとめら れている.

内容は, 当然, 著者の撮影法に対する考え方が反映さ れることになり，その当時までに発表された中から，一 つあるいは二つの撮影法が掲載されている。江副491 や小 川(51) は戸塚氏法 ${ }^{31}$ を採用し，横井・福田 ${ }^{46)}$ や熊谷 ${ }^{48}$ は, $\mathrm{X}$ 線束の斜入射投影を採用しているなど，種々の異なる 記述内容であり，全ての著書にわたって採用されている 撮影法はなかった。

視神経管撮影法では，全てに共通して用いられている 撮影法は見あたらなかったが, Goalwin 氏法のドイツ水 平面との角度 $\alpha$ と, 正中面とのなす角度 $\beta$ にもとづく撮 影法を採用しているものが多かった。しかし，穴の角度 は，種々の数值が提示されており，方法論は同一でも異 なる撮影法が存在していることが知れた。

この結果は, 専門委員会の19冊の書籍の調査結果の ${ }^{21}$, 同一部位で多くの撮影法が僅かの違いで存在し，また， 同一撮影法の名称でも異なる記述があるという報告と一 致した。

この結果から班報告では，同一の方法論からの撮影法 の記述で, 数多くの内容が存在することは混乱を招くと して，撮影法を何等かの方法で，体系的に整理すること が必要であると提言している。

我々はこのような結果もふまえて,さらに, 現在の医 療の水準，技術革新を目の当たりにしたとき，伝統のあ る撮影法を, 客観的・技術的にみて, もう一度, 整理を 
RADIOGRAPHIC METHODS OF OPTIC CANAL (PUBLICAITON)

\begin{tabular}{|c|c|c|c|}
\hline 1937 & Hideo Irie & $\begin{array}{l}\text { Roentgenographic examina- } \\
\text { tion and the way to treat } \\
\text { patients (Kanehara) }\end{array}$ & $\begin{array}{l}\text { Median sagittal plane at an } \\
\text { angle of } 50^{\circ} \text { to the cassette. } \\
\text { Deutsche Horizontal plane at an } \\
\text { angle of } 70^{\circ} \text {. Perpendicular } \\
\text { beam projection. }\end{array}$ \\
\hline 1964 & Yokoi \& Fukuda & $\begin{array}{l}\text { Radiography of the human } \\
\text { body (Nankodo) }\end{array}$ & $\begin{array}{l}\text { Median sagittal plane at an } \\
\text { angle of } 55^{\circ} \text { to the cassette. } \\
\text { Anthropological base plane at } \\
\text { an angle of } 85^{\circ} \text { (the chin to be } \\
\text { stuck out). X-ray beam, } \\
\text { cephalically at an incidence } \\
\text { angle of } 15^{\circ} \text {. }\end{array}$ \\
\hline 1966 & Masao Kagita & $\begin{array}{l}\text { Schematic radiography of } \\
\text { bone (Kanehara Shuppan) }\end{array}$ & $\begin{array}{l}\text { Median sagittal plane at an } \\
\text { angle of } 55^{\circ} \text { to the cassette. } \\
\text { The chin is stuck out, and } \\
\text { anthropological base plane } \\
\text { inclined } 12^{\circ} \text { backward. X-ray } \\
\text { beam, perpendicular. }\end{array}$ \\
\hline 1969 & $\begin{array}{l}\text { Sadayoshi } \\
\text { Kumagai }\end{array}$ & $\begin{array}{l}\text { Radiographic technique of } \\
\text { bone (Ishiyaku Shuppan) }\end{array}$ & $\begin{array}{l}\text { 1) Median Sagittal plane at an } \\
\text { angle of } 55^{\circ} \text { to the cassette. } \\
\text { X-ray beam, cephalically at an } \\
\text { incidence angle of } 17^{\circ} . \\
\text { 2) Haltman method }\end{array}$ \\
\hline 1971 & Masayoshi Ezoe & $\begin{array}{r}\text { Radiographic technology } \\
\text { (Nanzan-do) }\end{array}$ & $\begin{array}{l}\text { 1) Median Sagittal plane and } \\
\text { cassette at an angle of } 55^{\circ} \text {. } \\
\text { Anthropological base plane, } \\
\text { inclined } 15^{\circ} \text { backward. X-ray } \\
\text { beam, perpendicular. }\end{array}$ \\
\hline 1971 & $\begin{array}{l}\text { Shigeharu } \\
\text { Horio }\end{array}$ & $\begin{array}{l}\text { Plain radiography of bone } \\
\text { and } x \text {-ray anatomical } \\
\text { pictorial book } \\
\text { (Igaku-shoin) }\end{array}$ & $\begin{array}{l}\text { Median sagittal at an angle of } \\
52.5^{\circ} \text { to the cassette. Acoustic } \\
\text { pore made perpendicular to } \\
\text { anterior nasal spine. X-ray } \\
\text { beam, perpendicular. }\end{array}$ \\
\hline 1986 & Norihisa Ogawa & $\begin{array}{l}\text { Radiologic Technology } \\
\text { (Tsusho sangyo-Kenkyu-Sha) }\end{array}$ & $\begin{array}{l}\text { 1) Median sagittal plane at an } \\
\text { angle of } 55^{\circ} \text { to the cassette. } \\
\text { Anthropological base plane, } \\
\text { inclined } 12^{\circ} \text { backward (up to } \\
78^{\circ} \text { ). } \\
\text { 2) Totsuka method } \\
\text { 3) Rhese-Goalwin method } \\
\text { Median sagittal plane at an } \\
\text { angle of } 53^{\circ} \text { to the cassette. } \\
\text { Acoustic pore and anterior } \\
\text { nasal spine, made } \\
\text { perpendicular. }\end{array}$ \\
\hline
\end{tabular}

Table 1 Books on plain radiography in Japan

(Progress of radiography of foramen opticum) 
しなければならないのではないのか，そのような課題を 現在は抱えているのではないかと結論づけた.

\section{3. 撮影法を体系的に整理する方法の検 討}

\section{1 撮影法を体系的に整理する方法の基本的な考え 方}

撮影法を体系的に整理する方法を検討するにあたり， その基本的な考えをまとめておく必要がある。

撮影法は，一般的に診断サイドの要求から出発し，診 断学的要素の各項目が明らかにされ, その要求にもとづ いて撮影法の組み立て目標が明確にされる。そして被写 体の医学的要素の各データが検討され, 撮影技術学的要 素の各項目の検討から一応の撮影法の考え方ができる. さらに，現場の設備・装置の制約という要素も加味され て，実際に撮影法が作られるという経過を辿る.

したがって，撮影法を体系的に整理する場合も，この 基本的な枠組みの中で整理することが必要と考えられる。 さらに, 撮影法を体系的に整理する場合, 撮影法の結 果だけではなく，撮影法の組み立ての考え方・方法の違 い, データの違いを論理的に明らかにすることを基本に おくことも重要なことと考えられる。

\section{2 撮影法の組み立ての考元方・方法の違い, データ の違いをどのように整理するのか}

整理する方法については, 現在, 明確に提示されてい るわけではない。そこで戸塚の視神経管撮影法の分類研 究58)を参考にし，新たに考えることにした。

戸塚はつぎのように撮影法の作成の方法を分類してい ろ.

a ）頭部撮影の経験上，あるいは特定位を撮れば視神 経管像が得られるとのべたもの

b）多数頭蓋骨の統計的観測結果をあげて, 基点, 基 面を定め,これを撮影に応用したもの

c）まず，b）の方法により，さらに実際の撮影時に は, 各患者毎にそれぞれ若干の補正を行うもの

d）撮影の特殊装置を考案したもの

戸塚は，この分類を用いて，内外の文献の整理をして いる。

撮影法の作成には，多くの考え方があり，一見，まと めがつかないようにみえるが，戸塚の分類研究でわかる

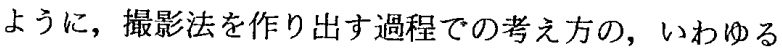
筋道を分類整理することで，その違いを明らかにでき， 撮影法をまとめることができると考えられる。

戸塚の分類は大きな枠で整理されており，撮影法の違
いをまとめるには，もっと細かな分類整理が必要となる。 そこで，つぎのような考方方から，もっと細かに分類 整理をし，しかも系統的に整理する方法を検討した。

$\mathrm{X}$ 線単純撮影は, 撮影目的と撮影部位が決まれば, 具 体的には撮影方向, 撮影体位, 基準となる部分の設定, $\mathrm{X}$ 線の入射点 - 入射角度, 撮影範囲, 撮影距離, 呼吸動 態などの各項目の内容が決定されて撮影法が作られるこ とになる。

この具体的な内容が決められる過程では, いくつかの 考える筋道, つまり，考え方の選択枝があると考えられ る.つまり，いくつかの選択枝の中から，どれかを選び 出して，穴の考光方に基づいて具体的な内容を決めてい ることになる。

そこで，予め筋道となるであろう選択枝をいくつか提 示しておき, 各項目での具体的な内容決定に際して, 選 択枝のどれを選んだかを明らかにして整理していく方法 を考えた。

撮影法の組み立ての考え方・方法の違い，データの違 いを整理する方法は，この選択枝の違いを明らかにする ことを基本におき, 診断学的要素から, 被写体の医学的 要素, 撮影技術学的要素と, 選択枝を選びながら, その 技術の作成の筋道を系統的に辿っていけるような方法と することとした.

この考え方から整理の方法を確立するためには, 診断 学的要素, 被写体の医学的要素, 撮影技術学的要素で, 撮影法を作る上で明らかにしなければならない項目を整 理し，そして，それぞれの項目ごとに選択枝を抽出し， 整理をしていかなければならないことになる.

なお，撮影法の組み立ての考え方・方法の違い，デー 夕の違いを整理する方法を, われわれは先にフローチャ 一トの形で報告しているが5), シンポジウムではチェッ ク・シートの試案を発表した。

チェック・シートは, 撮影法を考え作る過程での選択 の違いとその内容が分かるように, 縦軸に選択枝を配置 し, 横軸に被写体の 3 次元 (矢状面, 前額面, 水平面) の 3 つの分類項目を設け, 技術の対応整理や, 被写体の 解剖・機能データが各次元ごとに整理できるような形と したものである。

ここでいう被写体の 3 次元ごとの技術の対応整理とい う考え方は，Cieszyński ${ }^{59)}$ や，オルビックス・テクニッ ク, 日本でも小川 $\left.\right|^{51)}$, 增野 ${ }^{60)}$, 堀尾年) らの多くの研究者に よって取り入れられた考元であるが，内容表現が多少異 なっている。

われわれが提案したのは，人体の 3 次元である水平面， 
矢状面，前額面を基本に扮き，それぞれの断湎の分布と いう形とした。

つぎに。それぞれの項目とその選択枝の分類・整理の 検討結果を報告する。

\section{3 撮影法を作る上で明らかにしなければならない 項目の整理}

撮影法を作る上で明らかにしなければならない各項目 の抽出・整理は，各種の撮影法の研究と，つぎの文献を 参考にして検討した。

1）診断サイドの要求の整理の項は，特に文献（52。 53.54）を参考にした。

2）被写体の解剖・機能の項目の設定には各種解剖学の 文献（55．56。57）を参考にした。

3）撮影技術の，各項目は，標準化班報告 ${ }^{3)}$ ，われわれ の分類報告5)を用いて整理した。

(1)，(2)，(3)について以下の項目に分類・整理した。

(1) 謬断サイドが要求する診断学的要素の項目
a .どのような疾患が目的か
b . どのような機能状態でのX線像の要求か
c. 要求画像のタイプはどのようなものか
d．どのような部位がどのようにでていればよいの 加
e 。どのような利用の仕方なのか

（2）被写体の解剖・機能の項目

a，骨格の解剖でのデータの利用はどのようなもの か

b 、体表形態解剖でのデ一タの利用はどのようなも のか

c ，運動機能解剖でのデータ利用はどのようなもの か

d．放射線感受性でのデータ利用はどのようなもの か

e ．体位の安静度でのデータ利用はどのようなもの 加

（3）撮影法の組み立ての項目

a ．撮影技術の組み立て目標はどのようなものか

b，撮影技術の組み立て方針はどのようなものか

c．撮影技術の組み立て過程とその内容はどのよう なものか

1. 撮影方向は

2. 被写体の体位は

3. 撮影の基準設定は

4. X線入射角度は

5. X線入射点は
6. 照射野は
7. 撮影距離は
8. カセッテの設定は
9，構図・構成は
10. 呼吸は

d．X線写真の技術的な評価は，どのようなものか

（4）評価項目はどのようなものか

1.X線写真の品質からは

2. 患者の保護からは

3．現場技術・装置との関連からは

これらの項目は，撮影法を考え，整理する上で，必要 と考えられるものを，多くの研究論文扔よび書籍から抽 出して整理したものであるが，実際には，これらの各項 目は，現在，明確に分類整理されているわけではなく， 今までの種々の撮影法に用いられている組み立てでの分 類を調查して求め，一忘の試案を提示したものである。

つぎに，これらの各項目ごとに，どのような選択枝が 存在するか検討したので結果を，診断㐮イドの要求から， 順に報告する。

\section{4 診断サイドが要求する診断学的要素の各項目の 選択枝}

ここでの選択枝の分類・抽出は，臨床診断サイドの要 求を技術の組み立てに必要な形に分類整理することにお いた。

診断学的要素での選択枝の抽出・整理は, 診断学の著 書を参考にしたが，特に文献（1．52．53．54）を参考 にした。

Fig. 3 に示すように，5つの項目のそれぞれで選択枝 を求めて次の結果を得た。

(1) 描出要求がだされている疾患の分類整理

技術の組み立てを考えるにあたっては，まず，どのよ うな疾患のための写真かを明らかにし，何が目的なのか を明確にする必要がある。ここでは，畄のように6つの 選択枝と，さらに，その疾患 $(\mathrm{a} \sim \mathrm{n})$ を設定した。

例えば, 肩関節のX線撮影でも, 種々の要求があり, 撮影技術も必然的に異なってくる。ここの整理で概略の 技術の組み立ての指針が決められることになる。

(2) どのような機能状態での撮影要求かの分類整理 つぎに身体および局所部分の機能を, どのような状態 においたときの写真がほしいのか，何の目的でそのよう な機能状態にした映像情報を要求するのかを明らかにす る必要がある。ここでは，3つの選択枝を設定した。

例を膝関節にとると通常の撮影では, 運動機能的にみ て静的状態のスタチックレベルとなり, 片脚立位では自 
ARRANGEMENT OF CLINICALLY DIAGNOSING PHYSICIANS' DEMANDS

\begin{tabular}{|c|c|}
\hline & $\begin{array}{l}\text { 1) Trauma-- What type -- (a.....n) } \\
\text {-2) Inflammation }\end{array}$ \\
\hline \multirow[t]{5}{*}{ What type of disease is it? } & -3) Tumor \\
\hline & -4) System \\
\hline & -5) Unknown \\
\hline & L 6) Other \\
\hline & (1) Neutral (static) \\
\hline \multirow{2}{*}{$\begin{array}{l}\text { What condition of function } \\
\text { is it? }\end{array}$} & - 2) Dynamic \\
\hline & $L_{3) \text { Stress }}$ \\
\hline
\end{tabular}

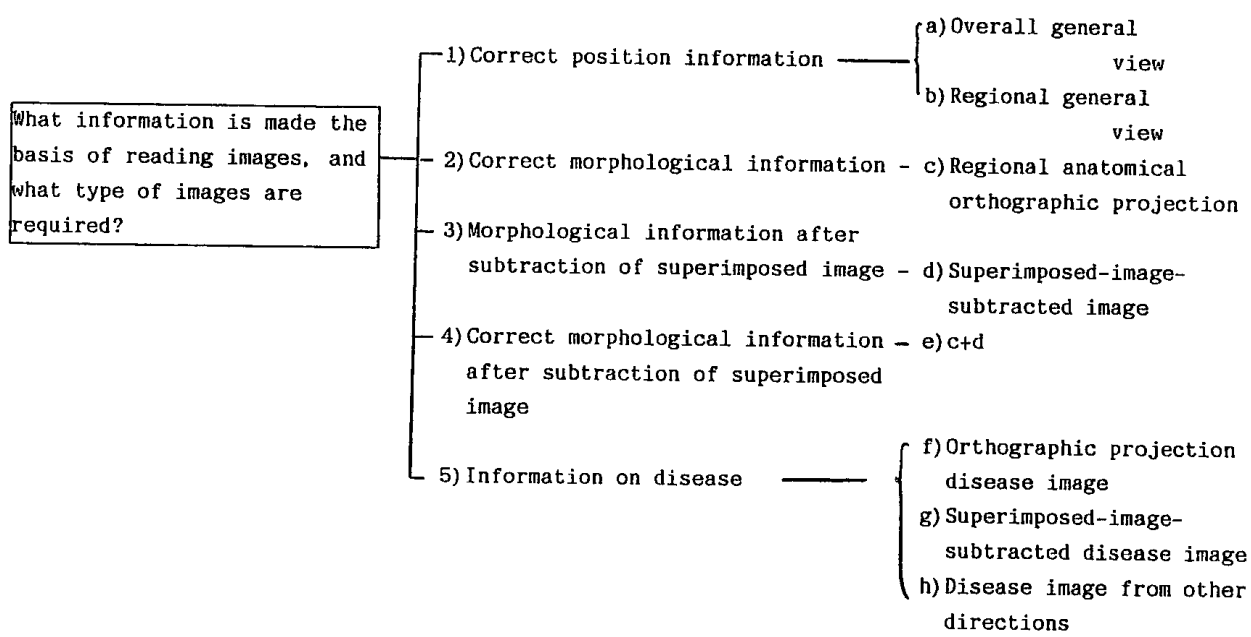

\begin{tabular}{|c|c|c|c|c|c|c|}
\hline $\begin{array}{l}\text { What section/site should be } \\
\text { visualized in what way? }\end{array}$ & \begin{tabular}{|} 
Pattern \\
Info. \\
site/area \\
\end{tabular} & $\begin{array}{l}\text { Morphologica1 } \\
\text { Info. }\end{array}$ & $\begin{array}{l}\text { Position } \\
\text { Info. }\end{array}$ & $\begin{array}{l}\text { Peripheral } \\
\text { Info. }\end{array}$ & $\begin{array}{l}\text { Contrast } \\
\text { Info. }\end{array}$ & $\begin{array}{l}\text { Dynamiq } \\
\text { Info. }\end{array}$ \\
\hline & $\begin{array}{l}\mathrm{a} \\
\cdot \\
\cdot \\
\cdot \\
\mathrm{n}\end{array}$ & & & & & \\
\hline
\end{tabular}

Fig. 3 Checksheet of radiographic technique construction (In reference to the section of the arrangement of clinicians' demands)

動のダイナミックレベルの撮影で, 前方引出し撮影は他 動のストレスレベルでの撮影と分類される.

ここでは，撮影技術の機能状態の対応が明確にされる。

(3) X線写真像で守饥ていなければならない基準の分 類・整理

それぞれの臨床X線写真には, 必ず守られていなけれ ばならない，損ねてはならないポイントがいくつかある. このポイントの一つに，読影に際し，その前提となる基
準通りのX線写真像が撮れているかどうかがあげられる. この基準を大きく図の 5 つの選択枝に分類し，さらに， その分類に対応する形で要求像のタイプと技術を考えた。 5 つの選択枝は，それぞれ，つぎのようにまとめられ る.

1）要求基準が正しい位置の投影像の場合は, 要求像の タイプを概観像とみなし，技術の組み立ての方針を正し い位置投影設定技術と位置づけられる。正中矢状面を基 
準にした左右対称性の撮影などがこれにあたる。

2）要求基準が正しい形態像の場合, 要求像のタイプは 局所の解剖学的に正しく投影される像となり，技術の組 み立ての基本を，ある部位の正しい解剖学的形態を得る ための技術とみなせる。視神経管撮影などがこれに該当 する。

3）要求基準が障害投影部の除去を目的とした場合, 要 求像は障害除去像となり，技術の組み立ての基本を障害 部位の重積率の軽減・改善の技術とみなせる。胸骨斜位 撮影などがこれに相当する。

4）要求基準が2）と3）にまたがる場合は，両者を合わせ た要求像の夕イプと技術の組み立てとみなせる。

5）要求基準が疾患情報に扔く場合は,要求像の夕イプ を，その疾患形態を正しく見ようとするためなのか，障 害部位の重積率の軽減・改善での像を見ようとするのか, 除去での疾患像なのか，違った方向からの疾患像の把握 なのかなどに分類整理できる。技術の組み立ての基本も， 同様に疾患形態を正しく描出するための技術か，障害部 位の除去での疾患像なのか，違った方向からの疾患像の 描出のための技術なのかに分類整理される。

要求基準となる選択枝は，際限なくありそうだが，実 際には, Fig. 3 に分類整理し，上記で説明した選択枝の 5 つに集約されると考えられる。そして，技術の組み立て の基本方針も，大きくみると，その選択枝に連なった 5 つの技術的詨応の選択枝を持つだけとみなせる。

例えば，正面と側面の概観撮影の他に，別の撮影法が 要求されるということは，正面あるいは側面の写真で何 等かの不備があったことになる。その不備は，正しい形 態情報が得られなかったのか，障害重積投影像があった のか，両者にまたがる不満があったのか，それともより 良い疾患投影像が得られなかったかのいづれかに該当す るに過ぎないこととして説明される。

したがって，撮影法を考える場合，そのどれに該当す るかを求め，それを改善する技術を組み立てれば良いこ とになる。

例えば Stenvers 撮影法 ${ }^{62)} は$, Shüller の経眼窩撮影法 の中で，正しい形態情報が得られなかった部分と，障害 となる重積投影部分がありこの二つの改善のために行 つた技術の組み立てとみることができる。歪率の改善部 分は骨半器官と䖮牛部の正投影, および錐体部の長軸の 最大長の投影に当り，重積率の改善は顔面頭蓋部の重積 除去として整理される。

これらの分類整理は，技術の組み立ての基本方針が明 確になるところであり，重要な部分であるといえる。
（4）部位・部分の描出要求のパタン分類整理

ある部位あるいは部分の写っていなければならないポ イントが指磻されたとき。これを映像上の分類で辺縁の 情報なのか，摆淡の情報なのか，形態の情報なのかとい う明確な当てはめができるように，分類・整理をし，技 術的対応を明確にできるようにした。

この項の展開は，ポジショニングというよりも，画質 に関する項となるので詳細は省略するが，別の機会に技 術の組み立てとの関連を明らかにして報告したい。

（5）利用方法の分類・整理

図のようにパタン認識レベルの利用なのか, 計量診断 なのか，選択枝を設けてその内容を明らかにし，精度は どの程度なのかを明確にし，技術のレベル・精度を決定 することが必要となる。

このように，蹦床診断サイドの要求の整理をし，技術 的な関連を明確にすることは，撮影技術の組み立ての違 いを明確にすることになり，撮影法を体系的に整理する 上からはとても重要なことと考えられる，今までこの部 分が明確に整理されていなかったところに，一種の暖味 さが生ま机たのではないかと思かれる。

\section{5 撮影技術の組み立て目標の分類・整理}

撮影技術の組み立て目標とは，診断学的な要求内容を 分類整理してまとめた各種の項目と内容を，被写体の3 つの次元ごとに分解整理し，各次元ごとに，どのような 映像として描出されるとよいのか，どのような機能状態 か，その利用のレベルはなどをまとめるものである。

Fig. 3 の診断学的な要求内容の分類整理をもとに，撮 影技術の組み立て目標を明確にするためのチェックシー 卜を検討した。

Table 2 に示すように，被写体の 3 つの次元を横軸に L,Fig. 3 の診断学的な要求内容の分類整理を緹軸にし て, 診断学的な要求内容を, 被写体の 3 つの次元ごとに 分解整理するものである。

例えば,副鼻腔のWaters 法は,つぎのように整理され る。

a）矢状面断の分布は，表の中の 3-d のルートを辿 り，重積像の除去をした状態での形態像の観察要求 となり，技術的には，障害部除去の技術の組み立て となる.その目標は上顎洞下縁と錐体上縁との分離 投影に打加机る。

b) 水平断の分布では, 表の 1-bのルートを辿り, 正 しい位置設定の局所外観像の観察要求となり，技術 的には，正しい投影位置設定技術の組み立てとなる。 その目標は正中矢状面上のものが正しく重積投影さ 
Table 2 Checksheet to put in order the objec tives of radiographic technique construction

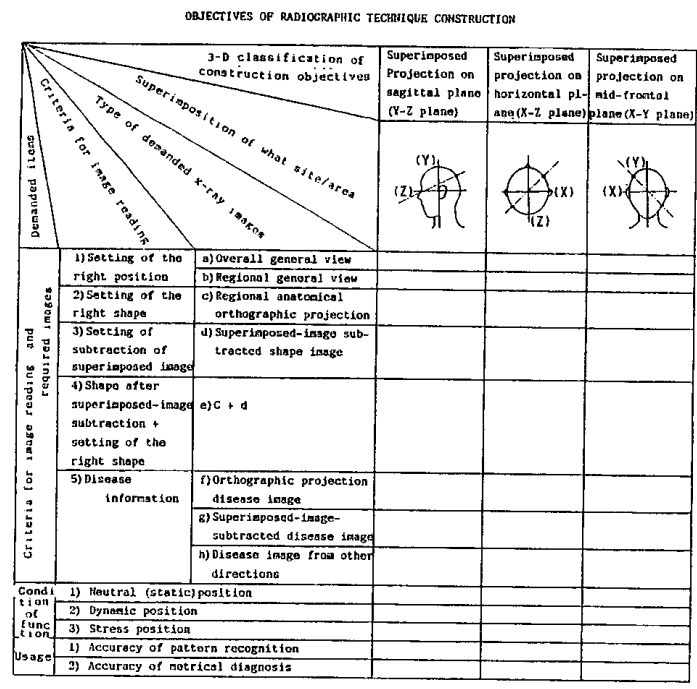

れることにおかれる。

c）前額面断の分布では, 副鼻腔のWaters 法の場合, 重積分布の目標ではなく，平面的な分布の目標が設 定されることになる. 要求基準は，1のルートを辿 り，正しい位置の設定となり，技術的には，正しい 投影位置設定技術の組み立てとなる。その目標は頭 部の左右屈がなく矢状面上のものが直線上に投影さ れることにおかれる。

このように, 3-Dの各次元ごとに要求基準と要求 $\mathrm{X}$ 線 像のタイプをたどり，技術の組み立ての基本方針や，ど のようなX線像として描出されるとよいかのポイントを 各次元ごとに明らかにしていくことが，撮影技術の組み 立て目標の分類・整理のポイントになる。

機能状態や，利用方法などについても同様に，該当す るものを選択し，3-Dのそれぞれでどのような内容とな つているかをまとめることになる。

\section{6 被写体の各種解剖・機能デー夕の分類 - 整理}

被写体の医学的要素の, 項目の設定には各種解剖学の 文献（55．56．57）を参考にした。

このデータ・シートのまとめ方についても，撮影技術 の組み立て目標の分類・整理の項と同じような形式をと り, 縦軸には各種の解剖・機能・放射線感受性などの項 目をおき，横軸に3-D を配した Table 3 のマトリックス とし，その中にデータを収録することとした。

このデータ・シートは，そのデータが各種解剖・機能 のどの分野にあたるのか, そして, 部分のデー夕なのか, 部位として構成されたときのデー夕なのか, 人体として 構成されたときのデータなのかなどを明確にしようとし
Table 3 Checksheet to put various data on a subject in order

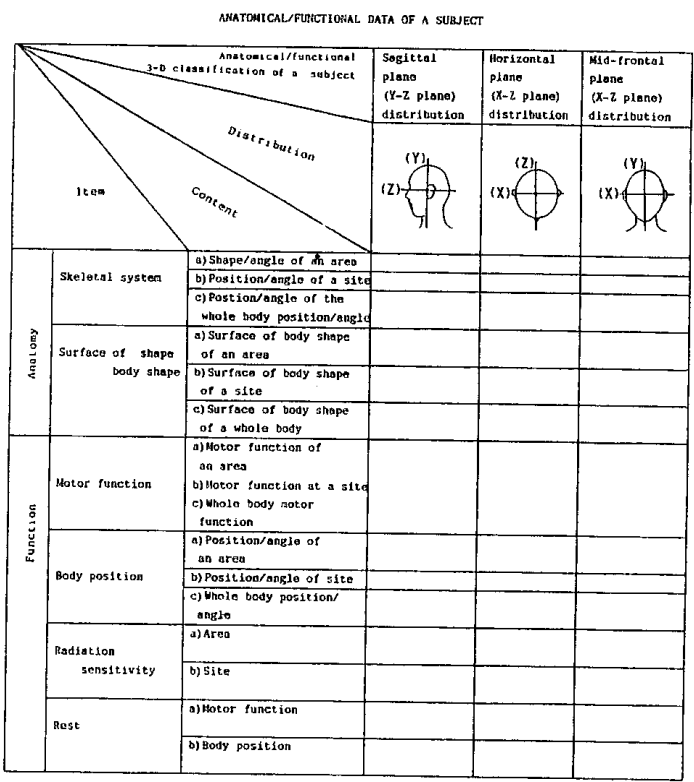

たものである。そして，データも統計的な取り扱いを基 本として，整理することを心がけることとした.

したがって，3-Dのそれぞれのデメンジョンで，どの 解剖・機能がどのようなデータとなっているのかを系統 的に整理, 把握されることになる.したがって, 撮影法 の組み立てにどのような解剖・機能とどのような次元の データを用いたかのチェック・シートとしても利用でき る.

このデータ・シートの内容の精度如何で, 撮影技術の 精度が決まることになるが, 統計的なデータが不足して おり, 今後, 本腰を入れた研究・整理が必要と考えられ る.

\section{7 撮影技術の組み立て方針の分類・整理}

標準化班報告3) および，われわれが報告した分類”を 利用して整理した.

技術組み立ての基本となる方針は，先にあげた診断サ イドの要求整理で 5 つに概略まとめられている. その基 本方針のもとに，撮影法を考え検討するとき，被写体の 体位変換方式なのか, X線束の斜入射方式なのかなどの 方針を予め明らかにするように選択枝を考えた。

選択枝は, 組み立ての方式, X線束に対する角度, 体 表指標の有無や相関データの選択, 撮影台の使用, 技術 精度の維持レベルなどにお゙いて，Table 4 にあげたよう な3-D を配列したマトリックスで整理することにした。

例をあげると，副鼻腔撮影のWaters 法の場合 ${ }^{63)}$ は, Caldwell の撮影に対する技術の転換であったこともあ 
Table 4 Checksheet to set up the policy of radiographic technique construction

POLICY OF RaD DOGRAPHIC TECHHIQUE COHSTRUGTYN

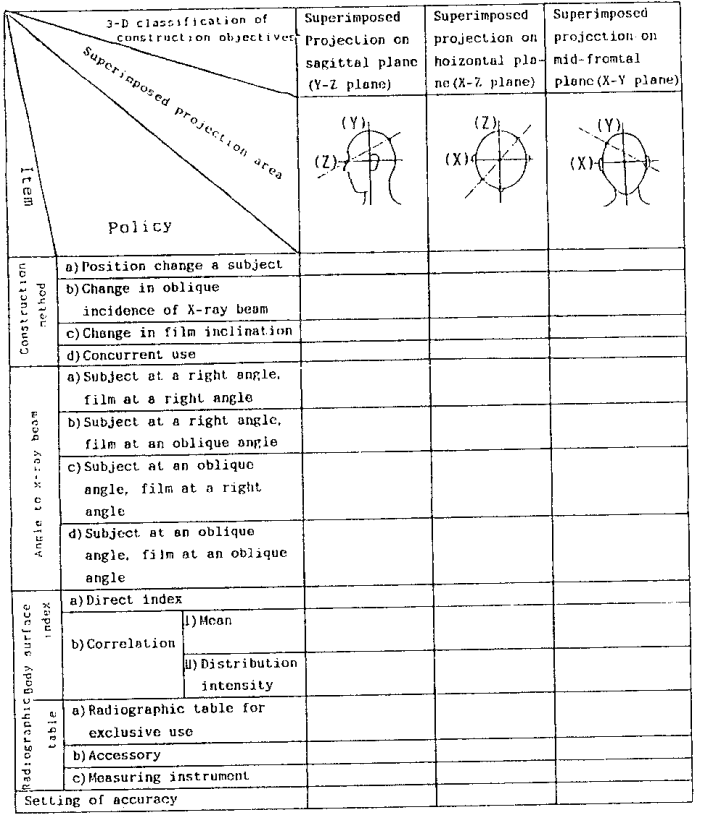

り，より明確に技術組み立ての方針と結果が明らかにな っている。

即ちフフィルムに対してX線中心線束は常に垂直であ るべきで，しかも，被写体は頒を突き出すという基本方 針をとっていることである。

これを選択枝のルートで整理すると，Waters 法の矢 状面断での組み立て方式は，被写体の体位変換法方式で， X線束に対する角度は，フィルムに垂直で被写体は任意 の触とするという方針にあたる。

一方, Caldwell 法は, 組み立てに際しての方針をどの ようにしたかは不明であるが，結果を整理してみると矢 状面断での組み立て方式は，X線束の斜入射変挨方式で， X線束に対する角度は，フィルムに斜入射で被写体は任 意の角度とするという方針にあたる。

このように3-Dの各次元ごとに方式を明らかにするこ とは，以後の技術を確立する重要な部分と考えられる。

\section{8 撮影技術の組み立ての考え方の筋道を明確にす \\ るための分類・整理}

Table 5 に示す単純X線撮影法の具体的な各項目は, 今まで整理してきた診断サイドの要求，撮影法の技術目 標, 被写体の各種デ一夕，撮影技術の組み立て方針の資 料に基づき，評価項目も加味されて検討されることにな る。

これらの各項目の内容決定を系統的にまとめるには， やはり，それぞれの決定に際しての筋道を明らかにする
Table 5 Checksheet to put in order the process of thinking of radiographic technique

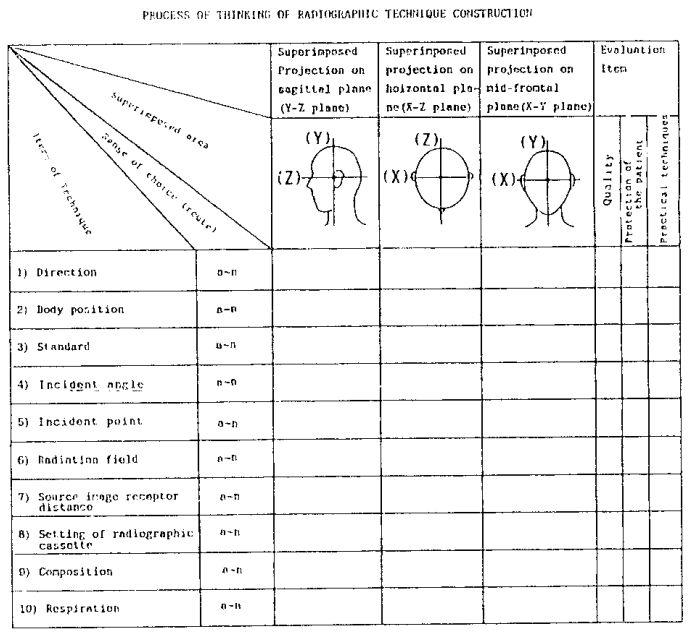

ことが必要となる。

したがって, Table 5の1〜10の項目で，それぞれの 項目ごとに考元方の筋道としての選択枝（図では $\mathrm{a} \sim \mathrm{n}$ としてあらわした）を明らかにしなければならない。

同時にTable 5 の横軸右端にあげた 3 つ評価項目を 整理して，その中の選択枝を明らかにしなければならな いことになる。

こ扎らの整理によって，撮影技術の組み立て・考え方 の筋道を明確にするためのチェック・シートはできあが 万。

Table 5 は，すべての撮影技術の項目を縦軸に羅列し た一覽表で表したが，実際には，各項目ごとに選択枝を 配列したチェックシートができあがることになる。

Table 5の 1 100項目の選択枝, および評価項目の 選択枝の抽出と，各項目のチェックシートをつぎに検討 したが，ここでは，紙数の都合で 1 １00項目の選択枝， および評価項目の選択枝の抽出結果のみを提示する。

標準化班報告3)および，わ狆われの分類 ${ }^{5)}$ を利用して 選択枝を抽出した。

\section{1. 撮影技術の項目の選択枝}

1. 撮影方向の決定の選択枝
a . 被写体の解剖学的な位置的関連加ら
b．患者さんの保護という関連から
c．現場の設定精度から
d。䉍便性加ら

2. 被写体の体位の決定の選択枝
a . 方向の決定と装置の制約から
b. 患者さんの保護という関連から
c. 機能状態の診断要求加ら 
d. 可検域を広げる観点から

\section{3. 被写体の基準設定の選択枝}

(体表から目的部が触知できたり,位置が確かめられ る場合)
a．それを基準にして設定

（体表から直接判断できない場合）

b ．基準線・面などを用い，その相関データを用い てそれを設定の基準とする

c . その部位の体表面上の指標そのものを，何等か の相関データから求め，それを設定の基準とする

d . その部位の体内配置と一致する他の部位の体表 指標の相関データから求め，それを設定の基準と する

4. 入射角度の決定の選択枝

撮影技術の組み立て方針・および方式の決定によっ て斜入射か，垂直投影かの基本が決定される。さらに 被写体の目的部の設定のあり方と相補的な関係で具体 的な角度はきまることになる。

（組み立て方針の項目の一部を入射角度の決定の選 択枝とみると.)

a . 被写体の目的部に直角あるいは平行で, フィル ムに垂直

b . 被写体の目的部に直角あるいは平行で,フィル 么に斜入射

c. 被写体の目的部に斜入射で, フィルムに垂直

d. 被写体とフィルムの両者の斜入射

(二等分線法のように被写体の目的部の設定に対 して斜入射投影ではあるが，X線歪率を極力おさ えた状態の斜入射)

5. X線入射点の決定の選択枝

(体表から目的部が判明する場合)

a．それを入射点の基準にする

（体表から目的部が分からない場合）

b. その目的部の体表面上の指標を求めて，それを 基準にする

c . その目的部位の体内配置と関連する他の部分の 体表指標を基準にする

d . 基準線・面を基準にした相関データを基準にす る

e ．斜入射投影になるように入射点を任意の距離だ け移動させる

6. 照射野の設定の選択枝

（限定する範囲が，体表から見える場合）

a、それを用いる
（体表から見えない場合）

b ．基準線・面との相関データを用いる

c．その部位での絞る簡囲の体表面の指標を求めて, それを用いる

d ．関連する他の部位の体表指標を求めてそれを用 いる

7. 撮影距離を設定する選択枝
a . 拡大ボケ, 歪みとの関連から
b . 撮影機器の出力などとの関連から
c . 拡散するX $X$ 線放射角度の利用の関連から
d．作業能率との関連から

8.カセッテを設定する選択枝
a . 通常のカセッテトレイに設定
b . 撮影台の上に斜め（任意の角度）に設定
c . 撮影台に垂直の設定

9. 構図・構成を設定する選択枝

（目的部が体表から判明している場合）

a 、それを目安に, 被写体一照射野一カセッテの構 図を構成する

（目的部が体表から不明の場合）

b . その部位の体表上の指標を求め，他の部位との 関連も加えて, 被写体一照射野一カセッテの構図 を構成する

c . 基準線・面との相関データとの関連から，被写 体一照射野一カセッテの構図を構成する

10. 呼吸の状態を設定する選択枝
a . 吸気の状態での呼吸停止
b . 呼気の状態での呼吸停止
c. 呼吸状態での撮影

2. 評価項目の選択枝

1.X線写真の品質
a ．パタンの精度
b ．照射野の精度
c . 構図・構成の精度
d ．画質の精度

2. 患者保護
a . 放射線被儤の軽減・防護
b . 苦痛の軽減
c．被写体の安定性

3. 現場技術での対応
a . 現場技術での精度
b ．現場技術での簡便性

撮影技術の項目の選択枝と評価項目の選択枝の一応の 試案を提示した。これらの選択枝を用い，チェックシー 
トが作成されることになるが，この中にはさらに検討し， 削除するもの，追加が必要なものがあると思われる。今 後，実際の系統整理の作業の中で，修正・追加を加えて いきたい。

\section{$3.9 \mathrm{X}$ 線写真の技術的な評価の分類・整理}

ポジショニングに関する評洒は，当初あげた撮影技術 目標の達成度から行うことができると考えられる。した がって，Table 3 の撮影技術の組み立て目標のシートを もとに，3-Dのそれぞれのデメンジョンで，達成しなけ ればならない目標がどれ程達成されたかを，各項目ごと にチェックす机ばよいことになる。具体的には，目標シ 一トに記載されていた内容と, 得られたX線写真の状態 を比較して，評価内容を Table 6 のチェック・シートに 記載してまとめることができる。

このような内容を盛り込み，整理した形のテクニカル レポートをまとめる事を，今後，心がけなければならな いのではないかと考えられる。

X線写真の臨床技術的な評価とは，決して診断する訳 ではなく，撮影技術の組み立て目標の内容について。ど れ程達成したかをチェックし，技術レポートをまとめる ことがまず基本的に必要な事と考えられている。

現在，このような臨床技術的なX線写真の評価に関し ての本格的な議論はなされておらず，一部には間違った 方向八評洒法が進んだきらいがあり，侮床X線画像の評 価はどうあるべきかを改めて検討すべきではなかろうか。 以上，途中で省略した筒所もあり，全てのチェックシ 一トを提示でをなかったし，具体例をあげることができ

Table 6 Checksheet to put in order the process of the technical assessment of radiography

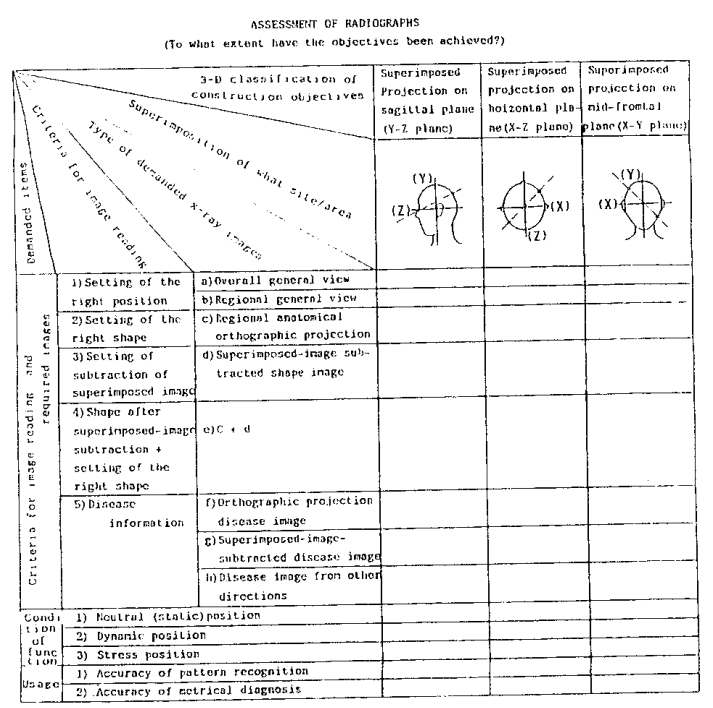

なかったが，撮影法を体系的にまとめるための考え方と， その試案の一端を提示した。

この撮影法を系統的に論理的に整理する方法は，それ ぞれの撮影法が，どのような選択枝を採用して作られた かを明らかにし，そして，どこの部分が論理的に筀白で あるか，嗳昧なのかを明らかにしていこうとするもので ある。当然のことではあるが，新たな撮影法を考える時 にもこのチェックシートを用いて検討することができ 万。

撮影法を相互比較する場合も，それぞれの項目におけ る選択枝の違いと，解剖・機能デー夕の選択の違いを明 らかにすることで違いを明確に指摘することができる。

\section{4.まとめ}

この報告では，現状の撮影技術の見直しをしなければ ならないのではないかという事と，さらに，撮影法はも っと系統的にしっかりした技術の枠組みでまとめ直さな け机ばならないのではないかという事を，資料をもとに 提案した。

X線写真の利用動向は, 計量唁断へ進んでおり, 高精 度の画像の要求が増えている事から, 精度という観点か ら，どう技術が答えていくのかが現在の課題となってい ることをのべた。

一方，X線単純撮影技術の研究の動向をみると，停滞 傾向にあり，今後，その対応を十分に検討する必要があ ることを明らかにした。

さらに，撮影法は，臨床に供されて有効に利用されて いるのだから良い，というものではなく，その根底にあ る技術組み立ての諭拠を，改めてまとめ直し，撮影法の 技術ベースを作ることが重要なことであり，今日の課題 であることを提示した。

本報告では，撮影法を体系的に整理する方法の考え方 とその試案の一端を提示した。

このまとめ方の特徴は，技術に関わる事項を診断サイ ドの要求から，技術的な評価までを網羅して各項を系統 的に分類し，その中に選択枝を設けて，撮影法を作って いく筋道，思考過程を，人体の3 次元構造体のそれぞ机 の次元ごとに明らかにしようとしたところにある。

個々の撮影法は，このチェック・シートによってその 考え方を明確に分類整理することができる，つまり，多 くの撮影法を共通の枠組みで比較検討することになり， 技術としての一貫性が生まれ，ここに一つの技術ベース ができあがるのではないかと考えられる。

この技術ベースをまず確立する事が，伝統のある単純 
撮影技術の現状の技術的課題と考えているが，そのため には,このチェック・シートのコンピュータ・データベ ース化への推進や, 臨床技術データの蓄積, 収集整理の ための, データベース化を進めていかなければならない と考えている.

今後の臨床技術は, より専門化され，より深く追求さ れるものと思われるが, 技術の組み立ての論理を明確に 持ち，基本を忘れることなく，取り組むことが重要なこ とではないかと考えられる.

\section{謝辞}

本シンポジウムに発表の機会を与えて下さいました後藤正 季大会長初め, 本部役員の皆様, そして育藤一彦座長に御礼申 し上げます、本報告についてご援助を賜わりました日本医科大 学第二病院放射線科 鈴木 洵技師長,御校閱下さいました日 本医科大学付属病院放射線科, 山岸一雄技師長に感謝申し上げ ます．また，石田勝哉先生，森矢達人先生には，本報告の撮影 技術に関する考え方に多大な御助言・御指導いただきました。 誌上を借りて感謝の意を表します。

\section{参考文献}

1）整形外科領域における疾患別撮影技術について，第 9 回放射線技術シンボジウム，日放技学誌，38-3， p. $308 \sim 348,1982$.

2）撮影技術委員会，撮影法検討班報告，岡本裕之，小 鴨義尚他：日放技学誌, 38-1, p. 93〜110，1981.

3）撮影技術委員会，佐藤貞男，川村義彦他：撮影法標

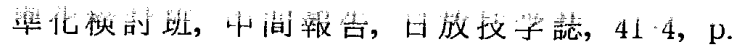
$649 \sim 657,1985$.

4）川村義彦，森矢達人他：撮影技術成立の技術的構造 化(1)，日放技学総会，予稿集，886，1985.

5）川村義彦，森矢達人，丸山智之他：撮影法の系統分 類作成法について，1.2.3.4.日放技学, 東京部会雑 誌, No. 21., Sep., p. 45〜48, 1986.

6）特集，画像診断に扔ける単純 $X$ 線写真の役割，画像 診断, 6-3, p. 13 75, 1986.

7) 片山 仁: 単純写真の価值と限界, 撮影分科会教育 講演，日放技学誌，40-4, p. 605～609，1984.

8）小田切邦雄: 骨単純撮影の意義と進歩, 臨床画像, 3-11, 1987.

9）廣島和夫，米延策雄：こ机でわかる整形外科 $X$ 線計 測，金原出版，東京，1986.

10）廣島和夫：計量 $X$ 線診断学74-92（編集，伊丹，西 尾), 整形外科臨床検査法, 金原出版, 東京, 1986 .
11) Theodore E. Keats, Lee B. Lusted, Atlas of Roento genographic Measurement Fifth Edition Chicage 1985.

12）中嶋寛之：スポーツ整形外科学, 南江堂, 東京, 1987.

13）症例によるスポーツ外傷・障害の実際：臨床スポー ツ医学, 臨時増刊号, Vol. 4., 文光堂, 1987.

14）川村義彦：スポーツ整形撮影技術の組み立て, 日放 技学, 東京部会雑誌, No. 28., July, p. 34〜39, 1988.

15）大貫一信：スポーツ整形における下肢の外傷と障害 時のX線検查の実際, 日放技学, 東京部会雑誌, No. 28., July, p. 26〜30, 1988.

16）放射線医療技術学叢畫(1)，放射線技術 QC プログラ 么, 日放技学，1988.

17）技術史委員会公開討論会, 研究発表からみた放射線 技術の推移と動向，日放技学誌，42-6，p. 888 894, 1986.

18）第36～45回，日放技総会，予稿集.

19）第42回総会座長セッション，日放技学誌，42-5,p. $676,1986$.

20）中村 康：視神経管及ビ其周囲ノ解剖学的研究並ビ 二視神経管「レントゲン」線写真撮影法二就テ，日 眼，31， p. 985 1014，1927.

21）伊藤益三郎：視神経管レ線撮影法に就いて, 眼臨, 45, p. 243.

22）金田 弘：余の考案せる「レ」線写真撮影用頭部傾 科器，山本レントグン゙学会訫，11-4，p. 295.

23）清水宗一郎・平松 博：視神経孔の「レ」線撮影法 並びにその影像, 十全会雑誌, 39-5, p. 1380.

24）光田光之助：視神経孔撮影用具に就いて，日放技学 誌, 2-8, p. 235〜236, 1936.

25）三宅 寿：余の考案せる頭蓋骨孔撮影補助具, 日放 学誌, 5-1, 1937.

26）野田静夫：視神経孔「レ」線撮影法，大阪放技学誌， 2-1, 1937.

27）笠間知彦，井上教保：余の考案せる視神経管方向線 測定器並びに視神経孔「レントゲン」線写真撮影に 就いて，眼臨，34，p. 301，1939.

28）原田達三郎：視神経孔管撮影の簡単なる一方法, 眼 臨, 35, p. 277, 1940.

29）牧野利三郎：余の考案せる視神経孔の「レントゲン」 写真撮影法，害践医理学，3-4.

30）舆村培四郎：視神経「レ」線像の撮影法と該管軸方 
向指示器, 日放学誌, 2, p. 163，1941。

31）城所信五郎，戸塚 清：視束管(視神経孔）「エッ未 ス」線写真新撮影法二就テ，日医放学誌，3-8，p. $653 \sim 670,1942$.

32）堌野 豊：視神経孔 X線撮影術式，日放技，第 8 回 総会, 1953.

33）鍵田政雄：視束管撮影法，日放技師会誌，83，p. 8, 1960 .

34）内藤義親，松浦 浩，伊藤謙助：対向点撮影法に関 する研究，日放技学誌，1961。

35）山岸一雄, 池田幸好, 武田弘志：視神経管撮影法, 日放技第23回総会，1968。

36）湯浅久司，土井信一格，中垣五月他：神経溝・管。 孔の撮影法，日放技学誌，31-5， p. 453〜 456, 1966.

37）森口武彦，中西省三：視神経管及び舌下神経孔撮影 の検討，日放技学誌，31-5，p. 456 460，1966.

38) Hartmann: Radiographie dr l'orbite et de sesorfices. Soc. d'Opht. de Paris. Juin.

39) Harry A. Goalwin: Die exakte radiograp hische Darstellung des Canalis opticus. a.d. Geb. d. Rontg. 3-4, 1924.

40) Brunetti : In difeso del mio methodo personale dell'assunzione crociata dei due canale otticia cranio fisso su stessa film. La rad. med. Vol. 19. fase. 9.

41) Busi : Di una nuova tecnica per la radiografica dei canali ottici. Ann. di rad. Fev.

42) Pfeiffer Raymond L: A new technique for roentgenography of the optic canals. Am. J. of Roent. and Rad. Ther. Vol. 29. No. 3.

43) Lysholm Apparatus and technique for Roentgen examination of the skull. Acta Rad. Suppl. 12. Vol. 6. p. 63 .

44) Camp and Gianturco: A simplified technique for roentgenographic examination of the optic canalis. Am. J. of Roentg. and Rad. Ther. Avril. Vol XX 1 X. No. 4, p. 547 549.
45）入江英雄：レ線唡査法卜患者ノ取扱方，金原商店， 東京, 1937 。

46）横井勝郎，福田 箺：人体X線撮影法，南光堂，東 京, 1964 。

47）鍵田政雄：図説骨 X 線撮影法，金原出版，東京， 1966.

48）熊谷定義：骨 X 線撮影法, 园歯薬出版, 東京, 1971.

49）江副正輔，田島聖正，森山有相：X線撮影技術学, 南山堂，東京，1971。

50）堀尾重治：骨単純撮影法とX線解剖図譜, 医学書院, 1971.

51）小川敬寿，山下一也他：放射線検査学 ( $\mathrm{X}$ 線)，通商 産業研究社，1986。

52）西岡清春：X線診断コード，分光堂，東京， 1984.

53）加藤斉之訳：X線診断演習, 広川書店, 東京。

54）川村義颜：X線撮影の限界を探る，X線写真の視覚 評価研究の立場加ら，日放技学，栃木支部雑誌，No. $3,5 \sim 9,1988$.

55）金子丑之助：日本人体解剖学， 1.2.3 . 南山堂, 東京，1979。

56) 藤原 知：体表解剖学，医歯薬出版，東京，1983。

57) 藤原 知：運動解剖学，医歯薬出版，東京，1981.

58）戸塚 清，大石省三：日本眼科全書，5-2，95～116， 金原出版，東京，1954。

59) Antoni Cieszyński Uber extraoraie Kieferaufnahmen mittels Rontgenstrahlen Fort a.d.. Gebieted. Rontgen. XVIII. 1, 1 26, 1912.

60）増野 豊：頭部X線撮影について, 日放学誌，1966.

61）島田 孝他訳：人体運動の基礎力学, 共同出版社, 東京, 1981 。

62) Stenvers, H.W. Roentgenology of the os petrosum. Archives of radiol. \& electrol., v. 22, pp. 97-112, 1917.

63) Waters, Charles A. A Modification of Occipitofrontal Position in the Roentgenography of the Accessory nasal sinuses Arch. radiol. \& rad. therapy, v. 20, pp. 15-17, 1915. 